\title{
AN ANALYSIS OF FEMINISM IN MERRY RIANA : MIMPI SEJUTA DOLAR MOVIE
}

\author{
Fitri Apriyanti \\ Bina Sarana Informatika University (UBSI) \\ fitri.fap@bsi.ac.id \\ Rahmi Aulia Nurdini \\ Bina Sarana Informatika University (UBSI) \\ rahmi.rau@bsi.ac.id
}

\begin{abstract}
In literary works, films cannot be separated from life, one of which discusses the issue of discrimination against women, a phenomenon that continues to be actively debated in society and gave birth to the feminism movement. Feminism can also appear through films, one of which is Merry Riana. Therefore, this paper aims to find out what is meant by feminism and how feminism is reflected in films and associated with liberal feminism. This study uses a qualitative method with sources from the original Merry Riana video. The writer uses data collection techniques from online sources. The data were collected by watching the film and understanding the film's dialogue several times and making observations to strengthen the analysis using the semiotic theory by Charles Sanders Pierce. The results of this study indicate that: (1) 8 data indicate the presence of elements of feminism in Merry Riana's action. (2) Feminism is shown through Signs, Objects and Interpreters. (3) In liberal feminism, it proves that women are not only focused on the private sphere, but can also be in the public sphere.
\end{abstract}

Key words: Literature, Movie, Merry Riana, Feminism

\section{INTRODUCTION}

Film is one of the mass communication media, namely communication through modern mass media. Films are present in part mass culture that appears along with the development of urban society and industry, as part of popular mass culture so that films become part of the mass media and have occupied an important position in people's daily lives. The stigma and stereotypes that form in society about women are more or less influenced by the media because the media only portrays a part of women as graceful and gentle. However, feminism in this era is that women can freely choose the opportunities they want without any limitations and by having the same position, so that every woman has the same rights, respects each other's functions and duties, also the safety of women. So, that none of the parties that they are in power feel better or higher in position than the others. Merry Riana's Film: Mimpi Sejuta Dolar by Hestu Saputro that adapted from the true story of Merry Riana's struggle.
Merry as a woman who never gives up, studies while working to survive while studying at NTU. Here comes the value more a woman who is not inferior to men, women can work to make a living. Merry is not thinking about anything people say. She only thinks about how to increase his pocket money so that she can survive in Singapore. Work is the only way that can help her financial condition. With an allowance of 10 dollars a week, if she doesn't do anything then things that don't happen will change. Only she can change the situation. Although she only works as a brochure distributor who is underestimated keeps doing the job diligently. Because she thinks it works as a brochure distributor is not a despicable job. Considered to only dwell on things that are domestic in the household. It's different from what's done by Merry, she is a pioneer for women to be able to move freely. Merry has proven its success. When she returns to Indonesia invited to speak in front of thousands of people because of her great achievements. Based on discussion above, the writers want 
to analyze the feminism reflected through Merry Riana : Mimpi Sejuta Dolar movie and how the feminism in Merry Riana : Mimpi Sejuta Dolar films represent women with Charles Sanders Peirce's semiotic approach and associate it with liberal feminism.

According to (Mulyati, 2019) "Literature is art used to describe written or spoken material or anything from creative writing to more technical or scientific works". It will imply that literature is an action of communicating inventive thoughts into a work that is then to be appreciated by people in general. (Schegloff, 2016) says "Literature is imitation through language, painting through visual image. Specifically, it is not just any imitation; what is imitated is not real but fictional, and need not have existed". According to Peter Widdowson in (Finnegan, 2015) that, "literature as written works, by which he means 'works whose originating form and final point of reference is their existence as written textuality." (Widdowson 1999: 15).

A film is a combination of images and sounds that can be enjoyed by the audience which contains expressions, emotions, and imaginations, ideas by the actors and as communicate information. According to Hunt in (Khairunas et al., 2018) states, "A movie is highly complex act of communication, and no act of communication is effective unless it takes into account how the recipient will receive it". It means, movie is the act of communication that the viewer can receive the meaning from the act of communication itself.

Based on (Bordwell et al., 2017) that, there are three major types of filmmaking: documentary, experimental, and animation.

In literature, characters and characterizations are important elements because they build the story. Characters are individuals who are created by the author to experience events and he appears in various events in the story. A character is a literary work in it and each character in the film describes a person as having a variety of characters. The characters that are formed and revealed through detailed physiognomic and are not only taught from parents but also support from the surrounding environment, while in narrative or drama works, characters are made for performances that are conveyed through various media.

According to Baldick in (Nuraeni, 2016) says "Character is a personage in a narrative or dramatic work, also a kind of sketch briefly describing some recognizable type of person." From the above definition, it can be concluded that each character in the film describes his own personality and behavior.

"Characters are familiar tropes because they are conveyed by diverse media, both fictional and nonfictional. Narratives, rhetoric, ideologies, frames, and the like shape our understandings largely through the characters they create." (Bergstrand \& Jasper, 2018).

Feminism is very broad but has the same point, namely a movement of gender equality in every aspect for women. then it can change people's opinion that women in this era are modern and reject the existence of differences in treatment because of gender differences. (Meinawati, 2017) says, "Feminism is concerned how the position of the subject of women in community. During this time women were considered as the other that their colleagues always waiting for defines and meant. The identity of the woman is always attached by a social construction".

According to Hook in (Hastuti et al., 2018) states, "Feminism is a movement to end sexism, sexist exploitation, and oppression." The meaning of this statement is that women want to be respected and also have value in human society without exploitation and oppression.

According to the book "Feminist" written by Tong in (Martiwi et al., 2017) states, there are eight kinds of feminism embraced by the feminist: (1) Liberal feminist, View of discrimination of women who are treated unfairly. Women should have the same opportunities as men to succeed in society. (2) Radical feminist, Assumes partrilianism system formed by power, domination, hierarchy, and competition. But it cannot be reformed and changed the way of thinking. (3) Marxist 
feminists and socialist, It is impossible for anyone, especially women to achieve true freedom in the middle people who embrace classbased system, where wealth produced by people who do not have the strength that is controlled by a few people who have the power. (4) Psychoanalytic feminist, The fundamental explanation for women's way of acting is rooted deep in women's psyche, specifically, in women's way of thinking about themselves as women. Relying on Freudian constructs such as the pre-Oedipal stage and the Oedipal. (5) Care-focused feminist, discuss issues why women are connected with reliance, community, and relationships. While men associated with dependence, independence and autonomy. These thinkers assume that in society there is a difference between the reality "feminist" and "masculine". (6) Multicultural / global / postcolonial Feminist, Focuses on the causes and an explanation of the status of women under men worldwide. This stream of well-known feminists has a strong commitment to emphasize differences between women and identify various kinds of women in order to cooperation with either. (7) Eco-feminists, Emphasizes the point that human is not only connected to other human, but also with the other creatures such as animals or even plants. (8) Postmodern feminist or third wave, it has thought to eliminate the disparities between masculine and feminine, sex, women and man. They tried to destroy the concept of the men who prevent women to position themselves with their own thoughts and not follow the man thought.

According to Saussure in (Chandler, 2007) states, The sign is composed of: The sounds and images, called the signifier, and the concepts of sounds and images, called signified" (Sidauruk, 2019).

According to Pierce in (L. Jay Bourgeois III Adam Ganz Andrew Gonce Keith Nedell, 2014) "consists of a triadic relationship containing the representamen (the sign itself that stands for something to somebody in some respect or capacity), the object (actual thing that the sign stands for) and the interpretant (created in the mind of the interpreter, an equivalent or more developed sign)."

Based on the semiotics of Pierce in (Chandler, 2017) stated, Peirce offered a triadic (three-part) model consisting of these functions: (1) The representamen: the form that the sign takes the 'sign vehicle'. (2) An object: something to which the sign refers (a referent), or which it represents. (3) An interpretant: the effect produced by the sign or the sense made of it.

\section{RESEARCH METHOD}

In this research, the writers used a qualitative approach by referring to Charles Sanders Pierce's semiotic theory to determine a feminism or gender equality movement contained in the film "Merry Riana : Mimpi Sejuta Dolar". The Writer data using Charles Sanders Pierce's semiotic theory is known as the triangle namely signs, objects and interpretant.

Then the data analysis technique is analyzed by taking pieces of the scene contained in the film " Merry Riana : Mimpi Sejuta Dolar " then analyzed about the struggle of Merry Riana : Mimpi Sejuta Dolar in moving a movement, namely feminism.

\section{RESULT AND DISCUSSION}

Feminism is reflected in Merry Riana : Mimpi Sejuta Dolar movie 


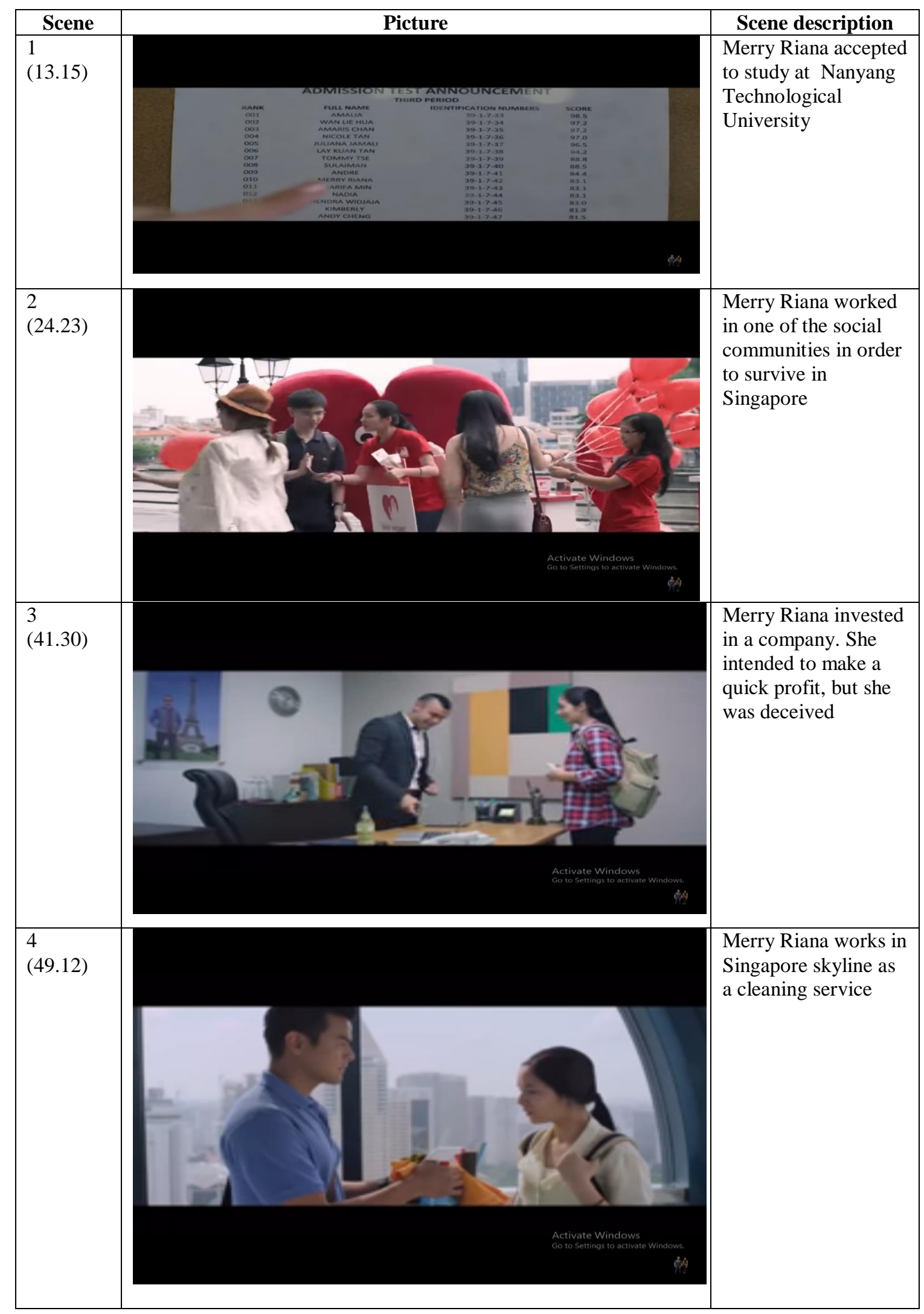




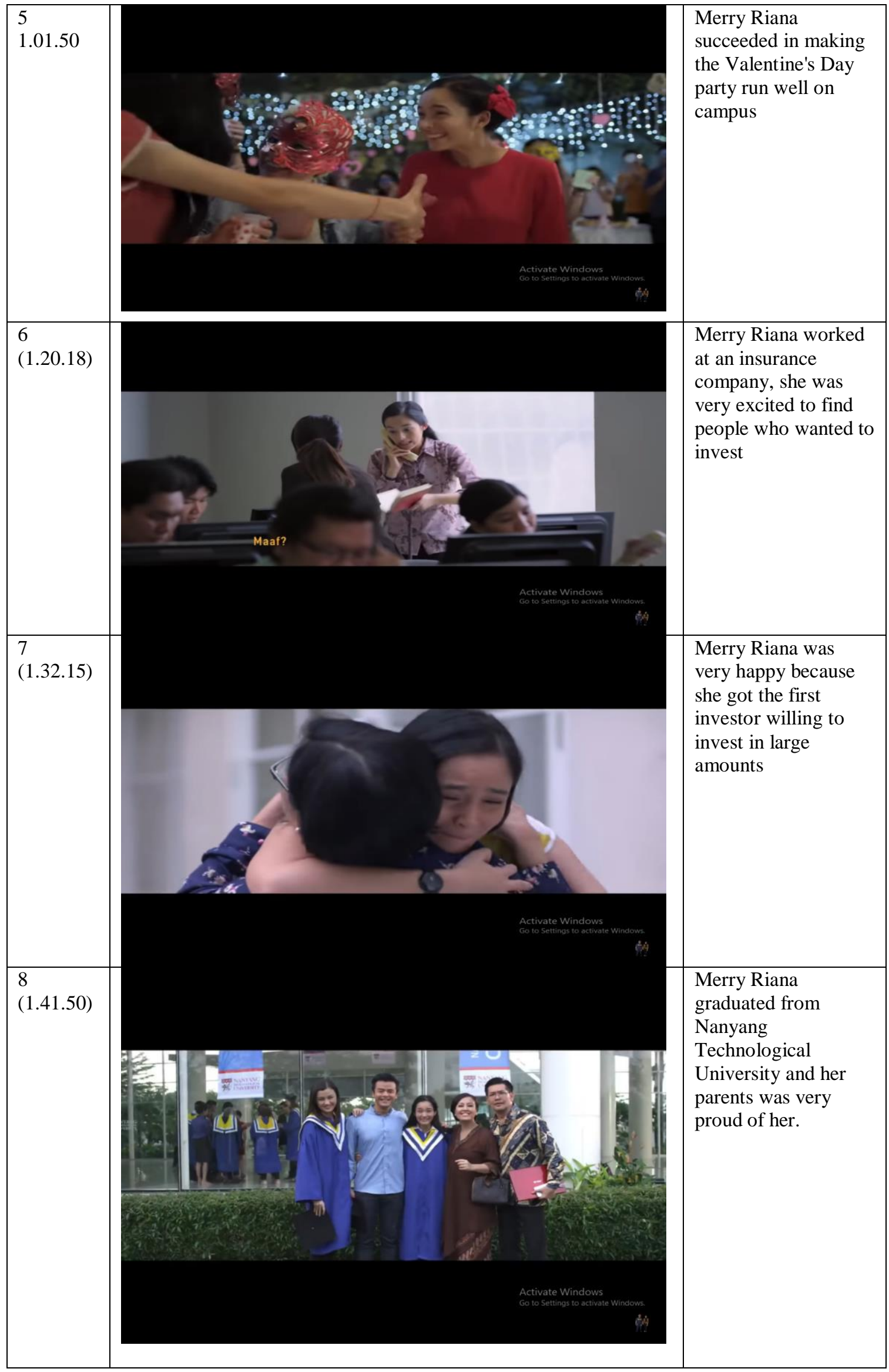




\section{Feminism Merry Riana's film associates it with liberal feminism}

Liberal feminism focuses on the equal rights of women and men in all aspects of life. The theory of liberal feminism emphasizes that every individual has the freedom to choose without any restrictions or restraints from the public or the law. As well as relating to rationality and separation between the private and public world. In the movie, Merry as a woman wants to have the same opportunities in education that is proven by he can pass the NTU entrance exam. Merry tried to apply for any job to get money to pay off student loans Merry can also do the job that men do (Alva). Merry got an offer for an internship at an insurance company and she got the first investor willing to invest in large amounts. Finally, She graduated from Nanyang Technological University.

\section{CONCLUSION}

Feminism is the theory that men and women should be treated equally in terms of politics, economics, and social status. So, feminism is a women's movement that demands emancipation between equal rights and justice with men.

In Merry Riana : Mimpi Sejuta Dolar movie, the writers concluded that to find feminism reflected in Merry's action, this

\section{REFERENCES}

Bergstrand, K., \& Jasper, J. M. 2018. Villains, Victims, and Heroes in Character Theory and Affect Control Theory. Social Psychology Quarterly, 5-20.

https://doi.org/10.1177/019027251878 1050.

Bordwell, D., Thompson, K., \& Smith, J. 2017. Film Art: Creativity, Technology, and Business. In Film Art: An Introduction. Mc Graw Hill Education.

Chandler, D. 2017. Daniel Chandler. In Most (Third). Routledge.

Finnegan, R. 2015. Where is language? An Anthropologist's Questions on Language, Literature and Performance. In Journal of Chemical Information article uses the theory of semiotic by Charles Sanders Peirce. The writer got several data related to feminism in Merry Riana : Mimpi Sejuta Dolar movie directed by Hestu Saputra and produced by MD Pictures. Signs of feminism in Merry Riana's film are Merry wanted to get equality in the field of education by following exam and passed. Equality in the social field Merry did what Alvan did and equality in the economy Merry applied for an insurance company.

Based on the analysis and discussion about Feminism in Merry Riana Film, the writer has a few suggestions as follows.

For researchers, when analyzing characters in a movie, researchers need to have a fundamental understanding of the film, if researching on feminism the researcher must explain more about feminism in its broadest sense and understand it, which should be done mostly by watching it repeatedly. Then collect data through the internet and other sources. The writer hopes that this paper can help the next researcher who wants to take the same topic.

For readers, the writers hope that this article can help readers understand what feminism has been described by the writer in this article and can be useful and applied in everyday life.

and Modeling. Bloomsbury Academic. Hastuti, D. P., Gunawan, D., \& Andriani, R. 2018. Liberal Feminism in Movie North Country Directed By Niki Caro. Wanastra: Jurnal Bahasa Dan Sastra, 10(2), 93-104. https://doi.org/10.31294/w.v10i2.401.

Khairunas, S., Desi Pratama, R. M., \& Wardani, E. S. 2018. Personality of Main Character in Jobs Films Directed By Joshua Michael Stern. Wanastra, 10(2), 2-12.

L. Jay Bourgeois III Adam Ganz Andrew Gonce Keith Nedell. 2014. Exploring the impact of interface signs' interpretation accuracy, design, and evaluation on web usability. The Eletronic Library, 16(4), 254-276. 
Martiwi, R., Karlina, E., \& Suharyadi, D. 2017. Liberal Feminism'S Aspect in Katy Perry'S Songs. Progressive, 12(2), 3-12. http://ejournal.nusamandiri.ac.id/ejurn al/index.php/progressive/article/view/7 13.

Meinawati, E. 2017. Liberal Feminism Of The Main Characters In Mirror Mirror Movie Based On Sociological Approach. Wanastra, IX(1), 66.
Mulyati, S. 2019. the Analysis of Five William Blake'S Poems. Wanastra: Jurnal Bahasa Dan Sastra, 11(2), 113-120. https://doi.org/10.31294/w.v11i2.5414. Nuraeni, C. 2016. A Psychopath Analysis on Amy' s Character In Gone Girl Movie. Wanastra, VIII(2), 46-52.

Schegloff, E. A. 2016. The Johns Hopkins University Press, Rice University. Social Research, Vol. 65, No. 3, CONVERSATION, 65(3), 535-596. 